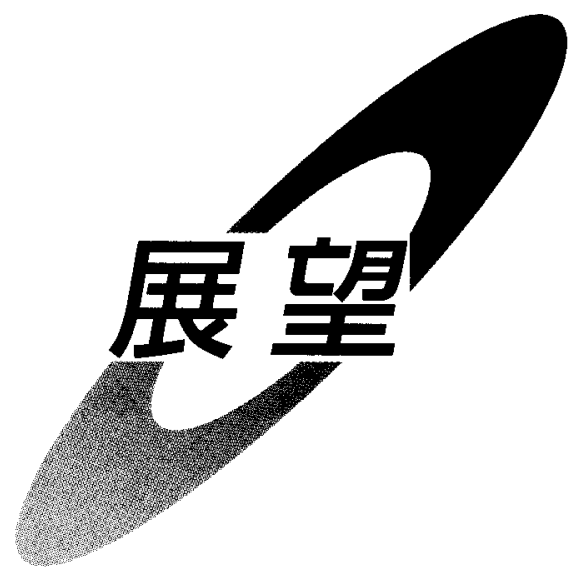

\title{
「メモリー効果」を 起こさないために
}

佐藤 祐一

皆さんの中に，二次電池内臓のシェーバーやステレオヘッドフォンを使用中に，以前はもっと永く使えたのにと思 われた方はいらっしゃらないだろうか.メモリー効果とは，ニッケル・カドミウム電池やニッケル・氷素電池のよう なニッケル極を用いる二次電池使用機器において，短時間使用しては充電することを繰り返していると放電電圧が低 下し，容量が短くなる現象で，その場合は電池を強制放電しては充電するということを数回繰り返すと回復する，昨 今ではその防止機構組み込みの充電器も市販されているようである。私達はこのメモリ一効果発生原因究明の研究を 数年間抗こなってきて，かなり内容が判って来た，その説明は別の機会にゆずるとして，われわれ人間社会にもこの ようなメモリー効果が存在するような気がしてならない，毎年，卒業研究のために研究室に入ってくる学生諸君をみ ていると，永年にわたって，君の力はこのくらいと思い込まされた，あるいは自分で勝手に思い込んできた学生のな んと多いことか。もっとやればできるのにと歯がゆい思いをすることがたびたびである。このような学生を変身させ るチャンスが卒業研究ではないかと考え，種々試みるのであるが，力およばずということを繰り返してきた，組織に 抒いても同じであろう。うまくいった方式を永年にわたって安易に繰り返してきた結果，周囲の状況が変わって制度 疲労を起こし，これをなんとかしなければと必死なのが昨今の諸状況ではないだろうか.

ここ数年間にわたって歴代の編集委員長以下役員諸氏が緜命な努力を続けてこられた結果，わが “Electrochemistry”はまさに花開こうとしている.これに安住し, その発行をルーチンワーク的に行っていてもしばらくは安泰で あろうが，それではメモリー効果を抗こし，衰退するのは目に見えていよう．今回はからずも大役を㧍拈せかり， 身の引き締まる思いである．試みに 1990 年と 2000 年の本誌の掲載論文内容を分類し てみると，前者では電池： $24.2 \%$ ，固体イオニクス：12.1\%，七ンサー：14.2\%等， 後者では電池： $21.0 \%$, 固体イオニクス : $19.7 \%$, バイオ関連 : $16.2 \%$, センサーと 電気分析： $12.8 \%$ 等である.春秋の大会では圧倒的に電池関連の発表が多いが, 論 文ではバイオ関連が増えており，センサー関連の論文にも生体関連物質の分析法が多 く，これらを含めると電池関連に匹敵し，今後の方向を暗示しているようである．論 文内容を分類してみて, あらためて本誌（本学会）の強みはラチチュードが広くて特 定の分野に固執することなく，電気化学現象に関連する様々の領域を貪欲に受け入れ て抢り，どの方向にも変わりうる可能性を持っていることであるのを認識した．編集 委員諸氏のご協力を仰ぎつつ, 高いアンテナを張りめぐらせて, 常に変身する努力を 続けたい. 電気化学の今後を摇るがすような大発見, 大発明の第一報がぜひ本誌から 発せられるようにと会員の皆様に強く希望致します。

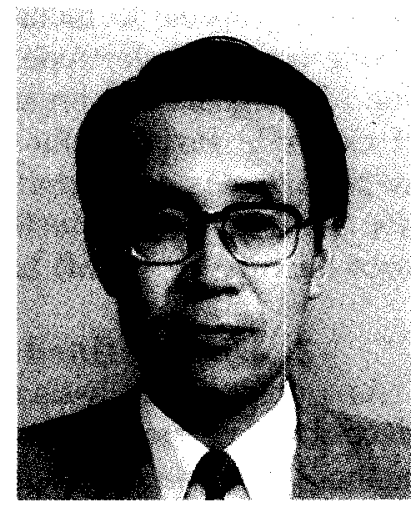

Yuichi SATO 本誌平成 13 年, 14 年度 編集委員長 神奈川大学工学部教授 